\title{
THE PRESUMPTION OF HARM IN EU PRIVATE ENFORCEMENT OF COMPETITION LAW - EFFECTIVENESS VS OVERCOMPENSATION
}

\author{
Dr. Lena Hornkohl, LL.M. (College of Europe) \\ Max Planck Institute Luxembourg for International, \\ European and Regulatory Procedural Law \\ 4, rue Alphonse Weicker \\ L-2721 Luxembourg \\ lena.hornkohl@mpi.lu
}

\begin{abstract}
The main issue that is still disrupting private enforcement of competition law is the calculation of damages. The 2014 Damages Directive contains some alleviations. Particularly Article 17(2) Damages Directive foresees a rebuttable presumption that cartels cause harm. Despite the clear statement in Recital 47 Damages Directive that this presumption should not cover the concrete amount of harm and studies that vary significantly regarding the typical overcharge, some Member States have created presumptions related to the amount of harm. Other Member States want to expand the presumption to non-cartel violations. This article takes a comparative analysis of the different Member States approaches and attempts to test the Damages Directive and EU competition law boundaries more generally. The article takes a sceptical perspective on some of the Member States' approaches and proposes other solutions to ease the predicaments of damage quantifications: (i) a focus on illicit gains, (ii) amending the calculation guidelines and create a EU-wide competition damages database, (iii) create further procedural measures, such as collective redress instruments, special legal venues for private enforcement of competition law and expert judges, and (iv) foster further party-led solutions.
\end{abstract}

Keywords: Competition Law, Private Enforcement, Damages Directive, Overcharge, Harm, Presumption of Harm, Quantification 


\section{INTRODUCTION}

Competition experts agree: the quantification of harm is the challenge in EU private enforcement of competition law. ${ }^{1}$ The 2014 EU Damages Directive $^{2}$ gives claimants who have suffered harm caused by an infringement of competition law a right to full compensation while avoiding overcompensation. A person who has suffered harm must be placed in the position in which that person would have been had the infringement of competition law not been committed. ${ }^{3}$ The necessary counterfactual analysis relies on a hypothetical and, thus, speculative scenario: what would the competitive situation have been but for the infringement? Finding the true counterfactual is impossible because it is impossible to know what would have happened but for the infringement. ${ }^{4}$ Hence, the obtainable damages always only represent the second-best optimum.

While the hypothetical but for analysis is typical for any damages claims, competition cases are more complex as the analysis often entails reconstructing entire market structures and "prices, sales volumes, and profit margins depend on a range of factors and complex, often strategic interactions between market participants that are not easily estimated" 5 . This puts limits on the expected certainty and precision of damages calculation. Therefore, the Damages Directive states in recital 45: "Quantifying harm in competition law cases is a very fact-intensive process and may require the application of complex economic models. This is often very costly, and claimants have difficulties in obtaining the data necessary to substantiate their claims. The quantification of harm in competition law cases can thus constitute a substantial barrier preventing effective claims for compensation.” Accordingly, the Directive itself contains several alleviating measures and is accompanied by a Practical Guide on quantifying harm ${ }^{6}$ that contains details on the usage of said economic models.

See, inter alia, Isikay O., Schadensschätzung bei Kartellverstößen — was kann das Kartellrecht vom Zivilrecht lernen?: Die Analyse zweier zivilrechtlicher Schadensphänomene, Duncker \& Humblot, Berlin, 2020, passim.

2 Directive 2014/104/EU of the European Parliament and of the Council of 26 November 2014 on certain rules governing actions for damages under national law for infringements of the competition law provisions of the Member States and of the European Union (Damages Directive).

3 Article 3(2) Damages Directive.

4 See Howard A., Too little, too late?: The European Commission's Legislative Proposals on Anti-Trust Damages Actions, JECLAP, Vol. 4, No. 6, 2013, pp. 455, 459.

5 European Commission, Practical Guide Quantifying Harm in Actions for Damages Based on Breaches of Article 101 or 102 of the TFEU, (SWD(2013) 205), par 16 [https://ec.europa.eu/competition/antitrust/actionsdamages/quantification_guide_en.pdf], Accessed 20 April 2021.

6 Ibid. 
The rebuttable presumption that cartel infringements cause harm in Article 17(2) Damages Directive is one of the core elements intended to facilitate damages actions because it reverses the burden of proof in favour of the claimant. Yet, it is not without critique. However, some even have called to follow those Member States, who, in the transposition of the Directive, gold plated the presumption and extended it to a concrete amount of harm or beyond cartel infringements. ${ }^{7}$

This article elucidates the Damages Directives and Member States approaches to the presumption of harm and discusses whether they are based on sound (economic) reasoning. The principle of effectiveness always has to be balanced against other principles and interests, particularly the principle of no-overcompensation, as demonstrated by Articles 3 and 4 Damages Directive itself. ${ }^{8}$ The goal of the Damages Directive is to aid claimants and guarantee the effective enforcement of competition law. Nevertheless, effective enforcement cannot trump everything, cannot set aside the general burden of proof and allow presumptions without any empirical foundation or substantial experience. The article takes a sceptical perspective on some of the Member States' approaches and proposes other solutions to ease the predicaments of damage quantifications.

\section{THE PRESUMPTION OF HARM DE LEGE LATA}

\subsection{The Presumption That Cartels Cause Harm in Article 17(2) Damages Directive}

The presumption in Article 17(2) Damages Directive has manifold origins and rationales. Studies and contributions that the Commission had gathered during the drafting period underlined that proving and quantifying antitrust harm is generally very fact-intensive and costly. ${ }^{9}$ It may require the application of complex economic models and constitutes one of the main obstacles in competition damages proceedings. Furthermore, the Commission heavily relied on findings from the famous Oxera Study ${ }^{10}$. The study contains an empirical analysis of a data set on cartel overcharges provided by Connor and Lande ${ }^{11}$ that Oxera adjusted based on

See below section 3 .

8 See also Mikelenas, V.; Zaščiurinskaite, R., Quantification of Harm and the Damages Directive: Implementation in CEE Countries, YARS, Vol. 10, No. 15, 2017, pp. 111, 115.

9 Studies, contributions and other accompanying documents for the Damages Directive are available at: [https://ec.europa.eu/competition/antitrust/actionsdamages/legislative_process_en.html], Accessed 7 April 2021.

10 Oxera, Quantifying antitrust damages: Towards non-binding guidance for courts, 2009, [https://ec.europa.eu/competition/antitrust/actionsdamages/quantification_study.pdf], Accessed 20 April 2021.

11 Connor, J.;Lande R., Cartel Overcharges and Optimal Cartel Fines in: Collins W,; Angland, J. (eds.), Issues in competition law and policy (ABA Section of Antitrust Law 2008). Connor and Lande provided 
their own criteria involving, for example, more recent cartels and estimates from peer-reviewed works. ${ }^{12}$ The study found that in $93 \%$ of the sample cases, cartels result in overcharge ${ }^{13}$, more than 9 out of 10 cartels. Moreover, several Member States already had adopted prima facie evidence or a de facto presumption of harm for cartel cases, mostly based on experience rules. ${ }^{14}$

Article 17(2) Damages Directive introduces a general rebuttable presumption that cartel infringements cause harm. The presumption only covers cartels as defined in Article 2(14) Damages Directive, even though the wording of Article 17(2) Damages Directive is unclear, as the provision uses the term' cartel infringements' and not 'cartels' itself $\mathrm{f}^{15}$. However, taking into account the Commission Proposal, including the Impact Assessment Report ${ }^{16}$ and recital 47 Damages Directive, the Directive apparently uses both terms as synonyms in the context of the presumption and the addendum 'infringements' seems to be a purely linguistical choice.

Harm in the sense of Article 17(2) Damages Directive includes both the actual loss and the loss of profit as set out in Article 3(2) Damages Directive. The wording 'cause' in Article 17(2) Damages Directive also ensures that the presumption includes the causal relationship between that harm and the cartel infringement, which is itself determined by Member State law subject to the principles of effectiveness and equivalence ${ }^{17}$. Typically, the presumption on the existence of harm applies regardless of the market level on which the claimant is active. For indirect purchasers, the presumption in Article 17(2) Damages Directive has important implications for and must be seen together with the presumption that pass-on has occurred laid down in Article 14(2) Damages Directive ${ }^{18}$. The presumption of harm in Article 17(2) Damages Directive in the case of indirect purchasers

additional 350 observations for the Oxera Study.

12 See in detail Oxera, op. cit., note 8, p. 90.

13 ibid, p. 91.

14 ibid, pp. 92-94. See for an overview Filippelli M., Presumption of harm in cartel damages cases, ECLR, Vol. 41, No. 3, 2020, pp. 137, 138. However, some of these prima facie cases were later reassessed by higher instance courts, see, for example, for the German Rails cases Rengier L., The German Federal Court of Justice's judgment in Rails II: Shifting the focus from liability to quantum in cartel damages?, GCLR, Vol. 13, No. 3, 2020, p. 97.

15 Critical Filippelli, op. cit., note 12, p. 140.

16 European Commission, Impact Assessment Report Damages actions for the breach of the EU antitrust rules (SWD(2013) 203 final), par 87, 88 [https://ec.europa.eu/competition/antitrust/actionsdamages/ impact_assessment_en.pdf], Accessed 20 April 2021.

17 Recital 11 Damages Directive, see Case C-298/04 Manfredi [2004] ECLI:EU:C:2006:461, par 64.

18 See hereto Botta M., The Principle of Passing on in EU Competition Law in the Aftermath of the Damages Directive, Eur Rev Priv Law, Vol. 25, No. 5, 2017, p. 881. 
includes the occurrence of harm on the first market level and, thus, helps to demonstrate part of the presumption requirements of Article 14(2)(b) Damages Directive. ${ }^{19}$

In turn, it is questionable whether the presumption of harm also covers umbrella pricing ${ }^{20}$, i.e. harm occurred to customers of cartel outsiders. The wording of Article 17(2) Damages Directive would be sufficiently open. ${ }^{21}$ However, even if umbrella effects occur in several instances, the decision of the Court of Justice in Kone $e^{22}$ has shown that a case-by-case assessment is necessary. The fact that cartel outsiders could set prices above normal competitive conditions may depend on various factors. This complexity contradicts a presumption. Furthermore, the legislators were aware of the umbrella-pricing phenomenon and would have been able to include an explicit reference to include umbrella pricing in the presumption.

In earlier stages of the drafting procedure, the Commission also considered that "average overcharges in price-fixing cases could serve as guidance for courts in determining the quantum of damages." ${ }^{23}$ However, in the final Directive, the presumption only covers the existence of harm. Recital 47 Damages Directive underlines that the presumption should not include the amount of harm. ${ }^{24}$ Nevertheless, a presumption that states that harm has occurred entails that damages must be greater than zero. ${ }^{25}$ Still, claimants have to prove the concrete amount of harm. Here the interplay with Article 17(1) Damages Directive will be crucial, which allows courts to estimate the amount of harm.

The presumption is rebuttable. This means that the presumption in Article 17(2) Damages Directive ultimately leads to a reversal of the burden of proof for the occurrence of harm. The infringer itself has the necessary evidence to meet the burden of proof that no harm has occurred in its possession.

19 See Kersting C., Kartellschadensersatzrecht nach der 9. GWB-Novelle, VersR, Vol. 1, No. 10, 2017, pp. 581, 583.

20 See hereto Franck J.-U., Umbrella pricing and cartel damages under EU competition law, Eur Compet J, Vol. 11, No. 1, 2015, p. 135.

21 Fritzsche A., Die Schadensvermutung: Auslegungsfragen zum Kartellzivilrecht nach der 9. GWB-Novelle, NZKart, Vol. 5, No. 11, 2017, pp. 581, 582.

22 Case C-557/12 Kone [2014] ECLI:EU:C:2014:1317.

23 European Commission, Commission Staff Working Paper accompanying the White Paper on Damages Actions for breach of EC antitrust rules (SEC(2008) 404), par 200 [https://eur-lex.europa.eu/legal-content/EN/TXT/PDF/?uri=CELEX:52008SC0404\&from=EN], Accessed 20 April 2021.

24 See also European Commission, Impact Assessment Report Damages actions for the breach of the EU antitrust rules, op. cit., note 14, par 89.

25 Filippelli, op. cit., note 12, p. 139; Iacovides M., The Presumption and Quantification of Harm in the Directive and the Practical Guide in: Bergström M.; Iacovides M.; Strand M. (eds.), Harmonising EU competition litigation: The new directive and beyond, Hart Publishing, Oxford, 2015, p. 300. 


\subsection{Member States' Approaches}

Many Member States have literally transposed the presumption of harm of Article 17(2) Damages Directive into Member State law, such as Ireland ${ }^{26}$, Lux$\operatorname{embourg}^{27}$ or the Netherlands ${ }^{28}$, without regulating, to the authors' knowledge, any other national peculiarities. On the other hand, in line with the minimum harmonisation technique of the Directive, several Member States have taken different approaches for the presumption of harm. These can be divided into four groups.

First, some Member States have altered the relatively narrow definition of 'cartels' in Article 2(14) Damages Directive to which the presumption of harm relates. Article 14(2) Damages Directive only covers horizontal cartel infringements between competitors and excludes decisions by undertakings or vertical restraints. ${ }^{29}$ Italy and Portugal included the national definitions of 'cartel', which go further than Article 2(14) Damages Directive and include every cartel infringement. ${ }^{30}$ The Spanish presumption also covers all cartel infringements since Spain did not transpose any definition of cartels. ${ }^{31}$ In Belgium, the definition of 'cartel' literally includes also decisions by undertakings or vertical restraints. ${ }^{32}$

Second, in Poland, the presumption extends beyond cartels to any violation of competition law. ${ }^{33}$ This includes non-cartel violations of Article 101 TFEU, such as information exchanges and vertical restraints and Article 102 TFEU violations. ${ }^{34}$ The aim is to facilitate and increase the popularity of private enforcement in Poland. ${ }^{35}$

26 Regulation 15 European Union (Actions for Damages for Infringements of Competition Law) Regulations 2017.

27 Article 2 Loi du 5 décembre 2016 relative à certaines règles régissant les actions en dommages et intérêts pour les violations du droit de la concurrence.

28 Artikel 1931 Burgerlijk Wetboek.

29 Filippelli, op. cit., note 12, p. 140.

30 Art. 2(1)(l) Decreto Legislativo 19 gennaio 2017, n. 3; Artigo 2(e) Lei n.o 23/2018.

31 Artículo 76(3) Ley de Defensa de la Competencia, en materia de ejercicio de las acciones de daños y perjuicios por infracciones del Derecho de la competencia.

32 Chapitre 13 Art. I.22 $\$ 12$ Code de droit économique; see Cauffman C., Belgium, in: Rodger B.; Sousa Ferro M.; Marcos F. (eds.), The EU Antitrust Damages Directive: Transposition in the Member States, Oxford University Press, Oxford, 2018, pp. 64, 77.

33 Art. 7 Ustawa z dnia 21 kwietnia 2017 r. o roszczeniach o naprawienie szkody wyrządzonej przez naruszenie prawa konkurencji.

34 Piszcz A.; Wolski D., Poland in: Piszcz A. (ed.), Implementation of the EU Damages Directive in Central and Eastern European countries, University of Warsaw Faculty of Management Press, Warsaw, 2017.

35 Bernatt M.; Gac M., Poland in: Rodger B.; Sousa Ferro M.; Marcos F. (eds.), The EU Antitrust Damages Directive: Transposition in the Member States, Oxford University Press, Oxford, 2018, p. 298. 
Third, the case of Germany is quite peculiar for two reasons. When first transposing the Directive, Germany had literally implemented Article 17(2) Damages Directive into national law. ${ }^{36}$ With a recent amendment of its national competition law, the legislator wanted to address the Rails I and Rails II jurisprudence ${ }^{37}$, which, inter alia, dealt with a causality assessment concerning affected persons and products, the so-called cartel affectedness (Kartellbefangenheit). In Rails I and II, the German Federal Court of Justice stated that there is, in fact, no prima facie evidence that cartels affect all transactions in the scope of a cartel. ${ }^{38}$ The German legislator was initially of the same opinion. ${ }^{39}$ This recently changed. The presumption in the new German law now explicitly extends to the cartel affectedness by stating: "It shall be rebuttably presumed that transactions concerning goods or services with undertakings participating in a cartel, which fall within the scope of a cartel in terms of object, time and place, were affected by that cartel." 40

Moreover, recently, a German Regional Court exhausted the possibility to estimate damages by using its own free estimation method instead of relying on economic experts. ${ }^{41}$ In the course of this free estimation, the court took the facts of the case, a contractual lump sum damage clause, as well as economic studies and comparisons to other Member States' courts into account and arrived at a 15\% overcharge. ${ }^{42}$ Hence, this method effectively led to a presumption of $15 \%$ overcharge through the back door. ${ }^{43}$

Lastly, despite recital 45 Damages Directive, three Member States have introduced presumptions relating to the amount of harm in their legal frameworks. Already before the Damages Directive, the Hungarian competition law included a rebuttable presumption stating that cartels cause an overcharge of $10 \% .{ }^{44}$ In the trans-

$36 \$ 33 \mathrm{a}(2)$ Gesetz gegen Wettbewerbsbeschränkungen.

37 Federal Court of Justice, 11.12.2018, KZR 26/17 - Rails I; Federal Court of Justice, 28.01.2020, KZR 24/17 - Rails II.

38 Federal Court of Justice, 11.12.2018, KZR 26/17 - Rails I, par 59; Federal Court of Justice, 28.01.2020, KZR 24/17 - Rails II, paras 27, 31.

39 BT-Drucksache 18/10207, 56.

40 See $\$ 33 a(2)$ Gesetz gegen Wettbewerbsbeschränkungen.

41 Regional Court Dortmund, 30.09.2020, 8 O 115/14 (Kart).

42 See in detail Makatsch T.; Kacholdt B., Estimation of cartel damages in competition litigation in Germany: 15 per cent as the new standard?, GCLR, Vol. 14, No. 1, 2021, p. 12.

43 Hornkohl L., Freie Schätzung der Kartellschadenshöhe nach \$S 287 ZPO: Eine Reaktion auf jüngste Entwicklungen, NZKart, Vol. 8, No. 12, 2020, p. 661.

44 Art. 88/G(6) évi LVII 1996, see Nagy C., Schadensersatzklagen im Falle kartellrechtlicher Rechtsverletzungen in Ungarn, WUW,Vol. 59, No. 09, 2010, p. 902; Noble R.; Pilsbury S., Is 10 per cent the answer?: The role of legal presumptions in private competition litigation, GCLR, Vol. 1, No. 3, 2008, p. 124. 
position of the Directive, Latvia followed the Hungarian approach and also introduced a rebuttable presumption of $10 \%$ overcharge for cartels. ${ }^{45}$ Romania went even beyond and introduced a rebuttable presumption that cartels cause an overcharge of $20 \%{ }^{46}$ The former Member State UK also envisaged a $20 \%$ rebuttable presumption of overcharge but abandoned the idea after a wave of criticism. ${ }^{47} \mathrm{In}$ the United States, cartels have long been assumed to have overcharged consumers by $10 \%$ when it comes to calculating fines, not in private damages litigation. ${ }^{48}$ The rationale for the three Member States who implemented presumptions related to the amount of harm is similar to Poland's: they want to aid claimants and create an attractive forum for private enforcement of competition law.

\section{THE PRESUMPTION OF HARM DE LEGE FERENDA: ROOM FOR MANEUVER?}

The previous section has demonstrated that several Member States have taken different approaches than the Damages Directives for their presumptions of harm. Some have called to equally extend the presumption of harm in a possible revision of the Damages Directive or on Member State level. These proposals require a critical assessment.

\subsection{The Presumption That Cartels Cause Harm Itself}

First, the presumption that cartels cause harm itself demands a critical evaluation. The presumption has been criticised for its reliance on the Oxera Study, primarily because the study itself heavily depends on, as mentioned above, the equally questionable Connor and Lande study. ${ }^{49}$ In general, several empirical studies on cartel overcharge exist that almost all use a data set provided by Connor ${ }^{50}$. Some studies

45 21(3) Konkurences likums.

46 Art. 16(2) RDONANȚĂ DE URGENȚ̆ nr. 170 din 14 octombrie 2020.

47 See Campbell S.; Feunteun T., Designing a Balanced System: Damages, Deterrence, Leniency and Litigants' Rights - A Claimant's Perspective in: Lowe P.; Marquis M. (eds.), European Competition Law Annual 2011: Integrating public and private enforcement, implications for courts and agencies, Hart Publishing, Oxford, 2014, p. 33; Hüschelrath K.; Müller K.; Veith T., Concrete Shoes for Competition: The Effect of the German Cement cartel on market price, J Competition Law Econ, Vol. 9, No. 1, 2014, pp. 97, 122.

482007 United States Sentencing Commission Guidelines Manual Chapter Two Part R \$2R.1.1, Commentary 3 .

49 Weidt C., The Directive on actions for antitrust damages after passing the European Parliament, ECLR, Vol. 35, No. 9, 2014, pp. 438, 442; Coppik J.; Heimeshoff U., Praxis der Kartellschadensermittlung: Empirische Evidenz zur Effektivität von Kartellen, WUW, Vol. 69, No. 11, 2020, pp. 584, 590.

50 Originally see Connor J., Price-Fixing Overcharges: Legal and Economic Evidence, 2005, [https://ssrn. com/abstract=787924], accessed 20 April 2021; for the follow-up studies see Connor J., Price Fixing 
are indeed methodological questionable, particularly because the available data is too diverse or outdated. ${ }^{51}$ However, the Commission itself critically assessed the Oxera as well as the Connor and Lande study and referred ${ }^{52}$ to an earlier version of a meta-study by Boyer and Kotchoni ${ }^{53}$. In this meta-study, Boyer and Kotchoni try to correct some comparability deficits and other problems of the data set provided by Connor.

Without going into detail about the validity of Boyer and Kotchonis findings at this point, the study indicates that while the majority of cartel-induced overcharges are in the low percentage range, in a majority of cartel cases, some form of harm has occurred..$^{54}$ This generally supports the presumption in Article 17(2) Damages Directive. Nevertheless, also Boyer and Kotchoni cannot find the existence of harm in $100 \%$ of cases. In fact, no study exists that establishes that harm occurs in every cartel case. ${ }^{55}$ Even in textbook cartel cases, no damage can occur, particularly if cartelists do not implement the cartel agreement ${ }^{56}$ or in the case of cartels that lead to a restriction of the innovation competition ${ }^{57}$. Thus, the general presumption that cartels cause harm is not in its entirety economically justified, even though the probability that damages occurred is very high. At least there is substantial room for a rebuttal.

Rather than economically, the presumption is procedurally justified. ${ }^{58}$ Next to the studies, the aim to facilitate damages actions was one of the rationales for the Article 17(2) Damages Directive presumption. ${ }^{59}$ However, it is questionable

Overcharges: Revised 2nd Edition,2008, [https://ssrn.com/abstract=1610262], Accessed 20 April 2021 Connor, J.,Price-Fixing Overcharges: Revised 3rd Edition, 2014, [https://ssrn.com/abstract=2400780], Accessed 20 April 2021.

51 See in detail below at 3.d.

52 European Commission, Impact Assessment Report Damages actions for the breach of the EU antitrust rules, note 14, par 88 .

53 See for the latest version Boyer M.; Kotchoni R., How Much Do Cartel Overcharge?, Rev Ind Organ, Vol. 47, No. 2, 2015, p. 119.

54 See figure at ibid, p. 123.

55 Coppik; Heimeshoff, op. cit., note 48.

56 Maier-Rigaud F.; Milde C.; Helm M., Textbook Cartels versus the Real Deal: Should We Be Surprised if Some Cartels Do Not Lead to Damage?, 2015, [https://ssrn.com/abstract=2578317], Accessed 20 April 2021.

57 Fritzsche, op. cit., note 19, p. 582.

58 See also in this vein Maier-Rigaud, Milde and Helm, note 55.

59 European Commission, Explanatory Memorandum: Proposal for a Directive of the European Parliament and the Council on certain rules governing actions for damages under national law for infringements of the competition law provisions of the Member States and of the European Union (COM(2013) $404 \mathrm{fi}-$ nal), par 4.5 [https://eur-lex.europa.eu/legal-content/EN/TXT/PDF/?uri=CELEX:52013PC0404\&from=EN], Accessed 20 April 2021. 
whether the presumption of harm alone can, according to recital 45, remedy the information asymmetry and other difficulties associated with quantifying harm, as it only relates to the existence and not the amount of harm. ${ }^{60}$ The presumption is nevertheless helpful for claimants because it reverses the burden of proof for the occurrence of harm and can work together with the possibility to estimate the amount of harm according to Article 17(1) Damages Directive. ${ }^{61}$

First, it can already create an evidentiary burden for claimants to prove the occurrence of harm due to an inherent information asymmetry. The so-called binding force of competition decisions does not include potential damage, published decisions do not necessarily contain helpful information, and access to the file is also limited. ${ }^{62}$ Even if such information asymmetries could be remedied with recourse to the disclosure provisions of the Damages Directive, disclosure is undoubtedly costly and may prolong proceedings at this early stage of a claim. ${ }^{63}$ The Article 17(2)-presumption is more appropriate and less intrusive. Now, the defendant, who is most likely in possession of the necessary evidence, must prove that the cartel did not cause any harm. ${ }^{64}$ Due to the inherent information asymmetry, this will not create an immoderate burden on the defendant.

Furthermore, the presumption works together with the possibility to estimate harm and creates further procedural efficiencies. Even in a situation where the defendants cannot rebut the presumption, but the claimants equally cannot prove a concrete amount of harm, the possibility for courts to estimate the amount of harm according to Article 17(1) Damages Directive exists. In that sense, the presumption facilitates damages actions and makes them more effective.

\subsection{Presumptions Beyond Cartels}

Some have called to extend the presumption of harm to competition infringement beyond cartels as defined by Article 2(14) Damages Directive. ${ }^{65}$ Such an extension could include decisions by associations, vertical restraints, or even the abuse of dominance. Information asymmetries also exist for claimants in these situations. ${ }^{66}$ Contrary to recital 47 Damages Directive, they are not exclusive to cartels due to

\footnotetext{
$60 \quad$ Iacovides, op. cit., note 23, p. 299.

61 See also Filippelli, op. cit., note 12, pp. 139, 140; Iacovides, op. cit., note 23.

62 Hornkohl L., The protection of confidential information during the disclosure of evidence according to the Damages Directive, ECLR, Vol. 41, No. 2, 2020, pp. 107, 108.

63 European Commission, Explanatory Memorandum, op. cit., note 58, par 4.5.

64 Howard, op. cit., note 3, p. 458.

65 Filippelli, op. cit., note 12, pp. 141, 142; Mikelenas and Zaščiurinskaite, op. cit., note 6.

66 Mikelenas and Zaščiurinskaite, op. cit., note 6, p. 121.
} 
their secretive nature. The secrecy of a cartel affects the proof of the violation of competition law itself, not the harm. ${ }^{67}$

Nevertheless, relying on experience rules and empirical studies is already questionable when it comes to cartels. As mentioned above, not even all the cartels as defined by Article 2(14) Damages Directive necessarily result in damages. Studies do not even exist for other competition law violations. In fact, the question if other competition law violations, such as information exchanges, cause harm, depends on various factors and a case-by-case assessment and cannot simply be presumed. ${ }^{68}$ Naturally, the Directive wants to help claimants and guarantee the effective enforcement of competition law in accordance with Article 4 Damages Directive. However, as initially mentioned, the principle of effectiveness does not trump everything. It cannot set aside the general burden of proof and allow presumptions without any substantial experience. The presumption that cartels cause harm itself is already quite a stretch in that regard. If cartels, the most severe competition law violations, do not even result in harm across the board, there is no room to include other competition law violations in a presumption of harm.

\subsection{A Presumption Concerning Affected Persons and Products}

As mentioned-above, new changes in German law include a rebuttable presumption of cartel affectedness. While the author is unaware of a German-style presumption in other Member States, generally, the courts of other Member States also have to determine whether certain transactions fall into the scope of those affected by a cartel. ${ }^{69}$ Other Member States could follow Germany and introduce a presumption that cartels affect all transactions in the scope of a cartel, which fits their system.

One has to distinguish here the questions of liability in principle and cartel affectedness. ${ }^{70}$ On the one hand, the liability in principle relates to the question of

67 Filippelli, op. cit., note 12, p. 139.

68 See, in detail, Deselaers W., Anscheinsbeweis für das Entstehen eines Schadens bei bloßem Informationsaustausch? in: Kokott J.; Pohlmann P.; Polley R.; (eds.), Festschrift für Dirk Schroeder: Europäisches, deutsches und internationales Kartellrecht, Otto Schmidt, Köln, 2018.

69 See, for example, District Court of Amsterdam, 12.05.2021, C/13/639718 / HA ZA 17-1255 et al., paras $3.21-3.32$.

70 This distinction is very prominent in German law, as the jurisprudence of the Federal Court of Justice distinguishes clearly between the establishment of liability in principle (Kartellbetroffenheit) and the cartell affectedness (Kartellbefangenheit). In the competition context see Otto J., (Kartell-)Betroffenheit und Schadensallokation nach der 9. GWB-Novelle, ZWeR, Vol. 17, No. 4, 2019, p. 354; Soyez V., Germany "Rail Cartel II": German Federal Supreme Court further strengthens private enforcement in Germany, GCLR, Vol. 13, No. 4, 2020, pp. R31-R32. However, other Member States also distinguish 
"whether the defendant is guilty of an anti-competitive conduct which — through the conclusion of sales transactions or otherwise - is capable of directly or indirectly justifying that the claimant suffered a damage." ${ }^{\prime 1}$ Following the case-law of the European Court of Justice, ${ }^{72}$ the claimant just need to show that the cartel was "liable to cause damage", which does not include any proof that the claimant has purchased cartelised products. ${ }^{73}$ Ergo, the liability in principle is part of the question if cartels cause any harm at all and, thus, the presumption of Article 17(2) Damages Directive. As mentioned-above, the presumption in Article 17 (2) Damages Directive includes the causal relationship between the cartel infringement and the occurrence of harm. Therefore, the presumption of liability in principle as part of the presumption of occurrence of harm can be based on the same abovementioned justification for the Article 17 (2) Damages Directive presumption.

On the other hand, cartel affectedness needs to be seperated from this question. Cartel affectedness deals with the question of wether the claimant has purchased a cartelised good. Cartel affectedness determines the causal connection between the cartel agreement and the existence of individual damages in a specific amount. ${ }^{74}$ It is, therefore, also in the understanding of Union law, ${ }^{75}$ part of the assessment that deals with the quantification or the amount of harm, which falls outside of Article 17(2) Damages Directive.

As we will see in the following section, presumptions relating to the amount of harm are problematic in themselves. A general presumption covering cartel affectedness is not free of doubt in itself. Member States are, in principle, free to determine the causality. Recital 11 Damages Directive clarifies that "the notion of causal relationship" is "not dealt with in this Directive" but remains governed by national law, subject to the principles of equivalence and effectiveness. ${ }^{76}$ As mentioned above, the probability is very high that cartels actually influence many legal transactions that fall within their scope regarding object, time and place. However, no empirical evidence or experience rules exist that undermine a presumption that all legal transactions with cartelists falling within the scope of a cartel were actually

between both levels, see the proceedings in the case of District Court of Amsterdam, 12.05.2021, C/13/639718 / HA ZA 17-1255 et al.

71 See Federal Court of Justice, 28.01.2020, KZR 24/17 - Rails II, par 25.

72 Kone, op. cit., note 20; Case C-435/18 Otis [2019] ECLI:EU:C:2019:1069.

73 Federal Court of Justice, 28.01.2020, KZR 24/17 - Rails II, par 26.

74 Federal Court of Justice, 28.01.2020, KZR 24/17 - Rails II, par 27.

75 Federal Court of Justice, 28.01.2020, KZR 24/17 - Rails II, par 27.

76 See hereto Strand M., Labours of harmony: Unresolved issues in competition damages, ECLR, Vol. 38, No. 5, 2017, pp. 205, 206. 
affected by that cartel. ${ }^{77}$ As the German Federal Court of Justice held in Rails I: "the implementation of the cartel agreements may encounter practical difficulties, especially in the initial phase. In this context, the fact that the exchange of information necessary for the implementation of restrictive cartel agreements is subject to restrictions resulting from the fact that the parties concerned particular exercise caution due to the risk of discovery may become important." ${ }^{\text {78 }}$ The critique mentioned above relating to the presumption of harm in Article 17(2) Damages Directive itself can be extended to the cartel affectedness, which equally does not exist across the board.

Again, just like with the presumption of harm itself, one has to take recourse to the principle of effectiveness. ${ }^{79}$ To avoid making cartel damages claims practically impossible or excessively difficult for claimants ${ }^{80}$, a presumption that transactions within the scope of a cartel actually affected the claimant will be helpful due to the reversal of the burden of proof. In many cases, claimants faced considerable difficulties because they were unable to prove that a concrete transaction was affected by a cartel due to a lack of relevant information. ${ }^{81}$ At the same time, such a presumption does not limit the defendant's rights in a detrimental amount. The defendant, who, as already mentioned above, has better access to information, can more easily prove that the cartel did not affect a concrete transaction. ${ }^{82}$ Furthermore, the presumption does not affect the actual quantification of harm, which the claimant still must prove. In that sense, a presumption of cartel affectedness in the German sense creates a balance between the principle of effectiveness and non-overenforcement, takes account of defendants' rights and is, therefore, procedurally justified.

\subsection{Presumptions Relating to The Amount and Quantification of Harm}

To further promote and simplify quantification and damages actions in general, some have called to extend the presumption of harm to the amount and the quantification of harm. These proposals have different dimensions. Some want to follow Hungary, Latvia and Romania and call for a rebuttable presumption that

\footnotetext{
77 See Federal Court of Justice, 11.12.2018, KZR 26/17 - Rails I, par 59; Federal Court of Justice, 28.01.2020, KZR 24/17 - Rails II, par 27, 31.

78 Federal Court of Justice, 11.12.2018, KZR 26/17 - Rails I, par 62.

79 BT-Drucksache 19/23492, 89.

$80 \quad$ Higher Regional Court Düsseldorf, 23.01.2019, U (Kart) 17/17, par 95.

81 See examples provided for by Rengier, op. cit., note 12, pp. 98, 99.

82 BT-Drucksache 19/23492, 89.
} 
cartels cause a specific amount of overcharge, primarily of 10\%. ${ }^{83}$ Others call for a presumption for an approximate or minimal overcharge that could be used as prima facie evidence. ${ }^{84}$ In turn, others support the above-mentioned free estimation method of the German Regional Court that lead to a de facto presumption of $15 \%$ overcharge. ${ }^{85}$

These proposals should be dismissed. In so far as a presumption should only cover overcharge, this might already not be very helpful, for example, for direct customers, to which the volume effect is just as significant or even more critical than overcharge. ${ }^{86}$ Beyond that, just like the presumption that cartels cause harm in Article 17(2) Damages Directive itself, supporters of presumptions relating to the amount of harm heavily rely on the studies mentioned above on cartel overcharge. Already for the presumption that cartels cause harm, this article questions the economic validity of the studies concerning the occurrence of harm in every cartel case.

However, the studies, a fortiori, lack typicality with regard to the amount of harm. Even if one takes into account the studies as a basis for a presumption relating to the amount of harm, the studies do not give rise to a typical overcharge. ${ }^{87}$ As demonstrated in Table 1, the means of the overcharge in the studies range from $20-$ $49 \%$ and the medians from $11-28 \%$. The deviations are too large to determine a typical overcharge that could be used as a basis for a presumption. Furthermore, the distribution of the overcharge within a study is very broad. Looking at the $O x$ -

83 Isikay O., Schadensschätzung bei Kartellverstößen — was kann das Kartellrecht vom Zivilrecht lernen?: Die Analyse zweier zivilrechtlicher Schadensphänomene, Duncker \& Humblot, Berlin, 2020, pp. 187200; Malinauskaite J.; Cauffman C., The Transposition of the Antitrust Damages Directive in the Small Member States of the EU: A Comparative Perspective, JECLAP, Vol. 9, No. 8, 2018, pp. 496, 509; Rauh J.; Zuchandke A.; Reddemann S., Die Ermittlung der Schadenshöhe im Kartelldeliktsrecht, WRP, Vol. 9, No. 2, 2012, pp. 173, 183; Klumpe G.; Thiede T., Regierungsentwurf zur 9. GWB-Novelle: Änderungsbedarf aus Sicht der Praxis, BB, 2016, pp. 3011, 3017.

${ }^{84}$ Kersting C.; Preuß N., Umsetzung der Kartellschadensersatzrichtlinie (2014/104/EU): Ein Gesetzgebungsvorschlag aus der Wissenschaft, Nomos, Baden-Baden, 2015, par. 58 - 66.

85 Thiede T., Zur Schätzung des Kartellschadens, NZKart, Vol. 8, No. 12, 2020, p. 657; Kersting C., 15 \% Preisaufschlag: Freie Schätzung des Kartellschadens beim Schienenkartell, WUW, Vol. 69, No. 11, 2020, p. 619; Makatsch; Kacholdt, op. cit., note 41.

86 Noble; Pilsbury, op. cit., note 43, p. 126.

87 See also Coppik; Heimeshoff, op. cit., note 48, p. 590; Brömmelmeyer C., Die Ermittlung des Kartellschadens nach der Richtlinie 2014/104/EU, NZKart, Vol. 4, No. 1, 2016, pp. 2, 8; Inderst R.; Thomas S., Schadensersatz bei Kartellverstößen: Juristische und ökonomische Grundlagen und Methoden, 2nd Edition, Handelsblatt Fachmedien, Düsseldorf, 2018, p. 98; Noble; Pilsbury, op. cit., note 43, p. 129; Rinnen F.; Wandschneider F., Ökonomische Überlegungen zur freien Schätzung des Kartellschadens durch das LG Dortmund, NZKart, Vol. 9, No. 1, 2021, pp. 11, 14, 15. See also recently Federal Court of Justice, 10.02.2021, KZR 63/18 - Rails VI, paras 38, 43. 
era Study alone, as demonstrated by Figure 1, the distribution of cartel overcharges range from $0-70 \%$ of the cartel price.

Table 1: Studies on cartel overcharges

\begin{tabular}{|l|c|c|c|}
\hline \multirow{2}{*}{ Study } & \multirow{2}{*}{$\begin{array}{c}\text { Number of } \\
\text { Cartels }\end{array}$} & \multicolumn{2}{|c|}{ Overcharge (\% of the cartel price) } \\
\cline { 3 - 4 } & $\mathbf{8 8}$ \\
\hline Posner $(1975)^{89}$ & 12 & 49 & Median \\
\hline OECD $(2002)^{90}$ & 12 & 16 & 28 \\
\hline Connor $(2005)^{91}$ & 674 & 49 & 11 \\
\hline Connor and Lande $(2005)^{92}$ & 674 & 49 & 25 \\
\hline Connor and Bolotova $(2006)^{93}$ & 395 & 29 & 25 \\
\hline Connor and Lande $(2008)^{94}$ & 674 & 49 & 16 \\
\hline Bolotova $(2009)^{95}$ & 406 & 22 & 20 \\
\hline Oxera $(2009)^{96}$ & 114 & ca. 20 & 20 \\
\hline Connor $(2010)^{97}$ & 1.089 & 46 & 18 \\
\hline Smuda $(2014)^{98}$ & 191 & 21 & 19 \\
\hline Connor $(2014)^{99}$ & 2.044 & 49 & 18 \\
\hline Boyer and Kotchoni $(2015)^{100}$ & 1.119 & 15 & 23 \\
\hline
\end{tabular}

88 In the studies, the overcharge is calculated as the actual cartelized price $(\mathrm{Pa})$ minus the counterfactual price but for the infringment $(\mathrm{Pb})$ in relation to the cartelised price: Overcharge $=(\mathrm{Pa}-\mathrm{Pb}) / \mathrm{Pa}$.

89 Posner R., The Social Costs of Monopoly and Regulation, J Polit Econ, Vol. 83, No. 4, 1975, p. 807.

90 OECD, Report on the Nature and Implications of Hard Core Cartels and Sanctions Against Cartels Under National Competition Laws, 2002, [https:/www.oecd.org/daf/competition/cartels/2081831.pdf], Accessed 20 April 2021.

91 Connor, Price-Fixing Overcharges, op. cit., note 49.

92 Connor J.; Lande R., How High Do Cartels Raise Prices? Implications for Optimal Cartel Fines, Tul L Rev, Vol. 80, 2005, p. 513.

93 Connor J.; Bolotova Y., Cartel Overcharges: Survey and Meta-Analysis, Int J Ind Organ, Vol. 24, No. 6, 2006, p. 1109.

94 Connor; Lande, op. cit., note 9.

95 Bolotova Y., Cartel overcharges: An empirical analysis, J Econ Behav Organ, Vol. 70, No. 1-2, 2009, p. 321.

96 Oxera, op. cit., note 8.

${ }_{97}$ Connor, Price Fixing Overcharges, op. cit., note 49.

98 Smuda F., Cartel Overcharges and the Deterrent Effect of EU Competition Law, J Competition Law Econ, Vol. 10, No. 1, 2014, p. 63.

99 Connor, Price-Fixing Overcharges, op. cit., note 49.

100 Boyer; Kotchoni, op. cit., note 52. 
Figure 1: Distribution of cartel overcharges (Source: Oxera, 2008).

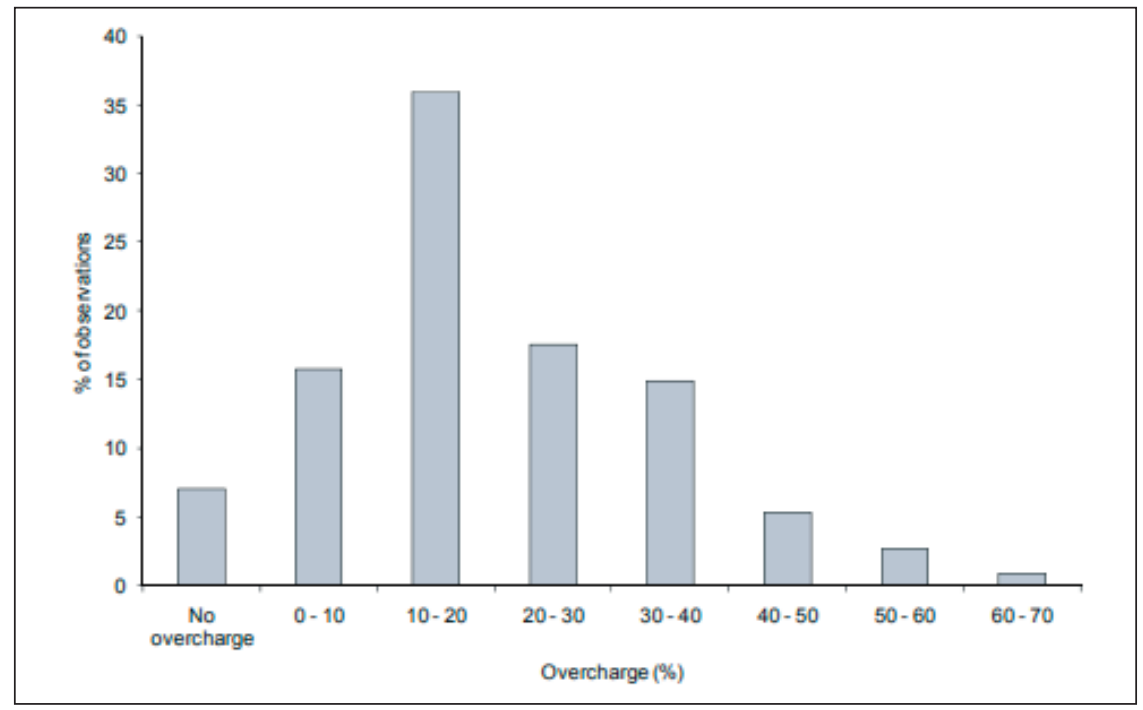

Furthermore, as indicated above, the studies are methodologically problematic. ${ }^{101}$ Early studies, such as Posner or the OECD, only analysed 12 cartels, a quantity too small to be statistically significant ${ }^{102}$ or representative ${ }^{103}$. The other following studies largely rely on the very heterogeneous Connor database, even though the selection criteria vary. Already timing-wise, the Connor database is questionable because it contains data on cartels from the last 250 years. The competition regimes have changed significantly in the last years. ${ }^{104}$ While mainly the leniency policy has led to increased cartel detection after its introduction in the EU, the latest developments, especially the current decline of leniency applications ${ }^{105}$ and the increase of private damages actions, have not been factored in. Even developments that date back 20 years are no longer necessarily relevant for today's analyses. In any case, 250-year-old cartels should not be taken into account. Moreover, the

101 See Filippelli, op. cit., note 12, p. 138; Weidt, op. cit., note 48, p. 442.

102 Similar Rengier L., Cartel Damages Actions in German Courts: What the Statistics Tell Us, JECLAP, Vol. 11, No. 1-2, 2020, pp. 72, 79, who compares statistical data on overcharges in German courts and states that the data is too diverse to come to any meaningful conclusion on typical quantification of damages.

103 See Cohen M.; Scheffman D., The Antitrust Sentencing Guideline: Is the Punishment Worth the Costs, Am Crim L Rev, Vol. 27, No. 2, 1989, p. 331.

104 Bechtold R., Kartell ist nicht gleich Kartell: Zur Indizwirkung von Bußgeldentscheidungen für den Schaden der Marktgegenseite und zur Bindungswirkung für den Schadensrichter in: Kokott J.; Pohlmann P.; Polley R. (eds.), Festschrift für Dirk Schroeder: Europäisches, deutsches und internationales Kartellrecht, Otto Schmidt, Köln, 2018.

105 Ysewyn J.; Kahmann S., The decine and fall of the leniency programme in Europe, 2018, Concurrences Art. $\mathrm{N}^{\circ} 86060$. 
studies cover a broad range of cartels that are not automatically comparable. ${ }^{106}$ As the studies rely on estimations themselves, different methods but also estimation biases and mistakes are possible, such as sample selection or publication biases. ${ }^{107}$

Even the meta-study of Boyer and Kotchoni, which tries to correct some of these deficits, is not necessarily applicable in a European context. ${ }^{108}$ The underlying data primarily covers multinational or non-European cartels. ${ }^{109}$ Studies that focus on Europe, such as Smuda, are subject to the just-mentioned biases and errors and, in any case, show that overcharges vary across periods or European regions. In fact, there are no reliable studies and no empirical evidence at all across different cartel offences and markets those cartels typically lead to a certain (minimum) harm (in Europe). The studies are so diverse that not even a high probability of a specific (minimum) amount could be established. On the contrary, many different factors have to be considered in the calculation of damages, such as the number and heterogeneity of cartelists, degree of organisation, barriers to entry, type of market, market coverage, geographical scope and duration of the cartel or possibility of tacit collusion in the counterfactual scenario, ${ }^{110}$ which argue for a case-specific assessment and an overall approach of these factors ${ }^{111}$.

Legal reasons also argue against any presumption related to the amount of harm, first of all, recital 47 Damages Directive. ${ }^{12}$ While the wording 'should' does not indicate an obligation and Member States are anyway not bound by recitals per $s e^{113}$, recital 47 stipulates the clear will of the European legislator not to introduce presumptions relating to the amount of harm. Second of all, presumptions of a specific amount of harm could also easily lead to overcompensation. In that case, the injured party could obtain an advantage from the damaging event, which runs contrary to most European damages law traditions and which the Damages Directive does not allow according to Article 3(3). ${ }^{114}$ Moreover, the studies have

\footnotetext{
106 Coppik; Heimeshoff, op. cit., note 48, p. 586.

107 ibid, pp. 590, 591.

108 Inderst; Thomas, op. cit., note 92, p. 94.

109 See Boyer; Kotchoni, op. cit., note 52, p. 120; see also to the difference between national and international cartels Noble; Pilsbury, op. cit., note 43, p. 129; critical with regard to the European dimension Rinnen; Wandschneider op. cit., note 92.

110 Inderst; Thomas, op. cit., note 92, pp. 94-99; Inderst R.; Schwalbe U., Das kontrafaktische Szenario bei der Berechnung von Kartellschäden, WUW, Vol. 61, No. 2, 2012, pp. 122, 131, 132.

111 Rinnen; Wandschneider, op. cit., note 92, p. 13.

112 Mikelenas; Zaščiurinskaité, op. cit., note 6, p. 120; Bodnár Miskolczi P., Hungary in: Piszcz A. (ed), Implementation of the EU Damages Directive in Central and Eastern European countries, University of Warsaw Faculty of Management Press, Warsaw, 2017, pp. 143, 144.

113 Hess B., Europäisches Zivilprozessrecht, 2nd Edition, De Gruyter, Berlin, 2020, par 4.58.

114 See Brömmelmeyer, op. cit., note 92, p. 8.
} 
shown a wide range of overcharge. In some cases, the overcharge goes far beyond a $10 \%$-, $15 \%$ - or even $20 \%$. A presumption could, therefore, also lead to an under enforcement. Even though a presumption would indeed be rebuttable, courts might be reluctant to deviate from such a 'save haven'. ${ }^{115}$ Even if that is not the case, the battle will just take place on the rebuttal stage, ${ }^{116}$ where defendants will provide evidence that the true damage is below the presumed amount, and claimants would still suffer from information asymmetry.

In that respect, reasons of effectiveness and efficiency cannot dispel these concerns. Promoters of presumptions relating to the amount of harm want to create incentives to sue and improve claimants' situation. However, as stated above, the principle of effectiveness is no means to an end, especially when empirically unfounded. ${ }^{117}$ Again, the presumptions that cartels cause harm is already a compromise. A presumption relating to the amount of harm goes far beyond that and places effective private enforcement above anything else.

Even if one would want to justify a presumption relating to the amount of harm as a policy choice, the presumption actually needs to be beneficial for claimants and encourage private enforcement. Yet, Noble and Pilsbury have shown that this is not necessarily true. ${ }^{118}$ In case the actual amount of damage is more significant than the presumed amount, the chance of winning must rise sufficiently to offset the reduced presumed amount of damages. ${ }^{119}$ In general, situations for smaller and larger claims differ considerably. In smaller claims, legal fees play a great role and could even come close to the amount of harm suffered. In these cases, only when the true overcharge is lower than the presumed overcharge, a presumption relating to the amount of harm actually encourages claims. ${ }^{120}$ This illustrates the small scope of application where a presumption relating to the amount of harm would make sense. In other situations, the presumption will, in fact, reduce the incen-

115 Noble; Pilsbury, op. cit., note 43, pp. 124, 125.

116 See Mikelenas; Zaščiurinskaitè, op. cit., note 6, p. 121.

117 See also Brömmelmeyer, op. cit., note 85, p. 8; Thole C., Freie Mindestschadensschätzung nach $\mathbb{S} 287$ ZPO durch das Gericht?: Das Urteil des LG Dortmund vom 30.9.2020 auf dem Prüfstand des Prozessrechts, NZKart, Vol. 9, No. 1, 2021, pp. 5, 7.

118 Noble; Pilsbury, op. cit., note 43, pp. 129-132, who also came to the conclusion that the incentive for cartelists to enter into cartels with a very high overcharge will be even enhanced through a $10 \%$ persumption of overcharge, while there will be a reduction to engage in cartels with a small effect on prices.

119 In the model of Noble and Pilsbury, the chance that the claimant will win the case if the presumption of a $10 \%$ overcharge is in place must be at least two-and-a-half times larger than the chance that the claimant wins a cartel damages case without a presumption to increase the incentive to litigate, see ibid, p. 130. ibid. 
tive to bring claims unless the chance of winning in the absence of the presumption is meagre because relying on the presumption would not be profit-increasing for claimants. ${ }^{121}$ For larger claims, incentives are considerably reduced, especially when the actual harm is more significant than the presumed. ${ }^{122}$ Furthermore, such a presumption will not even likely reduce litigation costs. A resource-intensive battle will instead take place on the rebuttal stage. ${ }^{123}$ Considering this, a presumption relating to the amount or quantification of harm does not increase the effective private enforcement of competition law.

\section{OVERCOMING THE QUANTIFICATION DIFFICULTIES AND MAKING DAMAGES ACTIONS MORE EFFECTIVE}

This article has demonstrated that substantially extending the presumption of harm is not appropriate. Nevertheless, damages quantification remains the main hurdle in private enforcement of competition law, even after the alleviations brought by the Damages Directive. Yet, one has to distance oneself from the obsession that an extended presumption of harm will be the only solution for the calculation problem. Other options are available to help with the quantification dilemma or ease and incentivise private actions for damages. This section includes first proposals that could give rise to further research.

\subsection{Illicit Gains and Damages Estimation, Unjust Enrichment and Restitution}

One option for claimants, particularly direct purchasers, could be a stronger focus on the illicit gains of the infringers. Illicit gains are the difference between cartel profits and the cartelists counterfactual profits but for the cartel. ${ }^{124}$ When there is no cost increase for the cartelists and the cartel involves most of the market actors, the illicit profits equal the additional payments of the cartelists customers', i.e. their actual loss. ${ }^{125}$ Even though cost increases or large numbers of firms outside the cartel could lead to a different outcome, illicit gains could be used to facilitate the estimation of damages itself.

\footnotetext{
121 ibid.

122 ibid, pp. 130, 131.

123 Hüschelrath; Müller; Veith, op. cit., note 46, p. 122; Makatsch; Kacholdt, op. cit., note 41.

124 Ellger R., Kartellschaden und Verletzergewinn in: Bechtold S.; Jickeli J.; Rohe M. (eds.), Recht, Ordnung und Wettbewerb: Festschrift zum 70. Geburtstag von Wernhard Möschel, Nomos, Baden-Baden, 2011, pp. 216, 217.

125 See Oxera, op. cit., note 8, p. 97; Hempel R., Privater Rechtsschutz im deutschen Kartellrecht nach der 7 GWB-Novelle, WUW, Vol. 53, No. 4, 2004, pp. 362, 370.
} 
They could, for example, be used as a minimum estimate of actual loss. ${ }^{126}$ Similar provisions or case law already exists in Germany ${ }^{127}$ or Denmark, and Sweden ${ }^{128}$. Special features of a case, such as the costs or the market coverage of the cartel, could be taken into account on a case-by-case basis, for which the cartelists hold the burden of proof. Even though, as explained above, there is always the risk that judges do not want to deviate from a presumption, the risk of overcompensation is low. Since illicit gains represent a direct transfer from the customer to the infringer, they will not be larger than the overcharge harm. ${ }^{129}$ The reversal of the burden of proof, on the other hand, could lead to substantial facilitation, at least for the actual loss. Claimants still hold the burden of proof for their loss of profits. Furthermore, claimants still hold the burden of proof for the existence of the illicit gains themselves, the foundation for estimating the minimum amount of harm. To calculate the illicit gains, the claimant needs a substantial amount of information that uniquely lies in the defendants' hands. ${ }^{130}$ To remedy such an information asymmetry, ${ }^{131}$ claimants must take recourse to the disclosure rules. Disclosure, in general, could substantially facilitate damages actions for claimants and eliminate information asymmetries, particularly for damages calculation. ${ }^{132}$

A similar approach could entail recourse to unjust enrichment and restitution instead of damages. ${ }^{133}$ Such a claim focuses on the illicit gain instead of the claim-

126 See in general Oxera, op. cit., note 8, 99; in favor of a legal presumption Alexander C., Schadensersatz und Abschöpfung im Lauterkeits- und Kartellrecht: Privatrechtliche Sanktionsinstrumente zum Schutz individueller und überindividueller Interessen im Wettbewerb, Mohr Siebeck, Tübingen, 2010, p. 402; Meeßen G., Der Anspruch auf Schadensersatz bei Verstößen gegen EU-Kartellrecht: Konturen eines Europäischen Kartelldeliktsrechts?, Mohr Siebeck, Tübingen, 2011, p. 425; in favor of prima facie evidence: Rauh J., Vom Kartellantengewinn zum ersatzfähigen Schaden: Neue Lösungsansätze für die private Rechtsdurchsetzung, NZKart, Vol. 1, No. 6, 2013, p. 227.

127 See $\$ 33 a(3)$ Gesetz gegen Wettbewerbsbeschränkungen.

128 Möllers T.; Heinemann A., The enforcement of competition law in Europe, Cambridge University Press, Cambridge, 2007, pp. 502, 529.

129 Oxera, op. cit., note 8, p. 99.

130 ibid, p. 98.

131 See Rauh, op. cit., note 131, p. 227.

132 Recital 15 Damages Directive, see in detail Hornkohl L., Geschäftsgeheimnisschutz im Kartellschadensersatzrecht: Die Offenlegung von Beweismitteln und der Schutz von Geschäftsgeheimnissen im Kartellschadensersatzrecht nach Umsetzung der Kartellschadensersatzrichtlinie, Mohr Siebeck, Tübingen, 2021 forthcoming, Chapter 1.

133 See Bernhard K., Making victims whole: A restitution approach to cartel damages, 2012, Concurrences Art. N 41907; Dreher M., Die Anfechtung und Abwicklung kartellbefangener Verträge nach SS 123, 812 ff. BGB: Bereicherungsrecht als Alternative zum kartellrechtlichen Schadenersatz in: Studienvereinigung Kartellrecht (ed), Kartellrecht in Theorie und Praxis: Festschrift für Cornelis Canenbley zum 70. Geburtstag, C.H. Beck, München, 2012; Westermann K., $\$ 11$ Zivilrechtliche Nichtigkeit kartellrechtswidriger Verträge und einseitiger Rechtsgeschäfte, bereicherungsrechtliche 
ant's loss. ${ }^{134}$ In most jurisdictions, unjust enrichment and restitution coincide with a reversal of the burden of proof and an improved situation for claimants. The claimant can simply demand repayment of the entire price paid. ${ }^{135}$ The claimant must, in turn, return the acquired cartelised good. Since the cartelised good usually has been resold or processed, the infringer can demand compensation. However, the infringer holds the burden of proof for the compensation, which is, principle, determined according to the market price. ${ }^{136}$ The information asymmetry can, thus, be further corrected, which gives claimants incentives to sue. A downside remains: restitution claims usually do not entail an award for the loss of profit. ${ }^{137}$ This makes restitution particularly interesting for indirect purchasers, who cannot claim a loss of profits. On the other hand, for intermediary suppliers or in abuse cases, the loss of profit often represents the 'lion's share' of the claim. ${ }^{138}$ Those claimants must additionally sue for loss of profits as damages.

\subsection{Amending the Calculation Guidelines: EU Competition Damages Database}

The Commission already provided guidelines for damages calculation, but those only contain various methods of calculation. They could further be amended to help claimants, who currently are dependant on complex economic calculations provided by costly economic experts. As stated above, many factors determine the amount of harm. These factors could be used to refine the guidelines and introduce a database of cases including a list of typical criteria relevant to determine cartel damages calculation based on a collection of Europe-wide precedents. ${ }^{139}$ Such collections of typical criteria should not be binding on courts but could help estimate damages in other, similar cases. ${ }^{140}$ German civil law already knows such an approach for the estimation of non-material damages. ${ }^{141}$ In that regard, the

Rückabwicklung kartellrechtswidriger Verträge in: Fuchs A.; Weitbrecht A. (eds), Handbuch Private Kartellrechtsdurchsetzung, C.H. Beck, München, 2019.

134 Oxera op. cit., note 8, p. 99.

135 Woeste K., Bereicherungsrecht als Alternative zum Kartellschadensersatz: Passing-on defense im Bereicherungsausgleich?, ZWeR, No. 4, 2018, pp. 392, 397.

136 Kahle C., Die Leistungskondiktion als Alternative zum Kartellschadensersatzanspruch: Zur Anfechtbarkeit und Rückabwicklung von Kartellfolgeverträgen, Nomos, Baden-Baden, 2013, p. 42; Mankowski P.; Schreier M., Zum Begriff des Wertes und des üblichen Preises, insbesondere in 5818 Abs 2 BGB: Zugleich zur Verzahnung von Zivil- und Kartellrecht, AcP, Vol. 208, No. 6, 2008, pp. 725, 745.

137 Woeste, op. cit., note 140, p. 400.

138 Howard, op. cit., note 3, p. 458.

139 See in detail Isikay, note 88, pp. 177, 178.

140 ibid.

141 Maslow C., Der Schutz des immateriellen Erfüllungsinteresses bei Vertragsverletzung durch Schadensersatz: Eine rechtsvergleichende Untersuchung auf der Grundlage des deutschen und englischen Rechts, Mohr Siebeck, Tübingen, 2015, p. 200. 
yearly reports of Laborde ${ }^{142}$ already contain helpful insights on damages calculation in the EU Member States. However, as Laborde repeatedly states himself, the reports are not complete and lack methodological uniformity and precision. The Commission, which could use the European Competition Network as a reporting system, would be better positioned to create such a database.

\subsection{Procedural Tools: Collective Redress, Concentrations and Expert Judges}

Several procedural instruments are missing in the Damages Directive and the Member States implementing laws, which could facilitate damages calculations and damages actions in general. Significantly, the possibility to join forces in different capacities could help claimants in bringing damages actions. An apparent first solution would be collective competition redress, which could save time and costs, particularly for small claimants. ${ }^{143}$ The complex damages calculation could be bundled together in such cases. Unfortunately, the recent Collective Consumer Redress Directive ${ }^{144}$ does not include competition law in its scope. Thus, collective competition redress remains in the hands of Member States, which could give rise to forum shopping. Here, at least the recent Trucks case of the Amsterdam District Court, which did not entail collective redress but where many individual claims were joined together, could serve as a good first step into the right direction. ${ }^{145}$

Notably, the possibility of a concentration of procedures on a national and international level could also be beneficial. The Damages Directive does not entail jurisdictional rules, and existing instruments are not always helpful. ${ }^{146}$ Even on a national level, rules on the concentration of proceedings are often missing. ${ }^{147}$ In Germany, for example, only on the state level, concentrations at one Regional Court for competition law claims are possible. ${ }^{148}$ Contrary, the mentioned Dutch Trucks case was bundled at the District Court of Amsterdam. ${ }^{149}$ The concentra-

142 See for the newest version Laborde J.-F., Cartel damages actions in Europe: How courts have assessed cartel overcharges: 2019 edition, 2019, Concurrences Art. N 92227.

143 See in general, inter alia, Şahin E., Collective Redress and EU Competition Law, Routledge, London, 2018.

144 Directive (EU) 2020/1828 of the European Parliament and of the Council of 25 November 2020 on representative actions for the protection of the collective interests of consumers and repealing Directive 2009/22/EC.

145 See the proceedings in District Court of Amsterdam, 12.05.2021, C/13/639718 / HA ZA 17-1255 et al.

146 Idot L., The international aspects of private enforcement after the Directive 2014/104/EU: Gaps in the EU system and competition between national laws, 2017, Concurrences Art. № 83833.

147 Wurmnest W., Forum Shopping bei Kartellschadensersatzklagen und die Kartellschadensersatzrichtlinie, NZKart, Vol. 5, No. 1, 2017, pp. 2, 10.

$148 \$ 89$ Gesetz gegen Wettbewerbsbeschränkungen.

149 See the proceedings in District Court of Amsterdam, 12.05.2021, C/13/639718 / HA ZA 17-1255 et al. 
tion of proceedings in one Member State or at least the concentration within the different Member States on national level, could bring further procedural efficiencies. The court could serve as a hub or collection point for damages actions against one defendant. ${ }^{150}$ For damages calculation, several aspects, such as the question of how the market would have evolved but for the infringement, are relevant in more than one claim. Furthermore, documents and other evidence relevant for damages calculation could be stored at this court.

Similarly, such a concentration could be combined with an extended specialisation of judges. In most Member States, cartel damages actions end up before ordinary civil courts. While the respective chambers often have a competition focus, the emphasis on competition expertise could be stressed even further. Nowadays, particularly the costs incurred for the engagement of economic experts could exceed the actual damages in case of small claims and is, therefore, prohibitive. ${ }^{151}$ Instead of or complementary to those expert witnesses, competition expert judges practising at these special competition venues could further facilitate damages calculation. For example, in Germany, Austria or Belgium, the commercial divisions of civil courts nowadays have commercial lay judges. These commercial judges come from the commercial community and sit on a panel together with ordinary judges. They are expected to assess a case based on their particular professional qualifications and business experience, which allows for a practical and appropriate judgment in commercial disputes that correctly assesses general business practices. ${ }^{152}$ In a similar vein, competition expert judges could use their own competition expertise, particularly when it comes to damages calculation.

\subsection{Party Involvement: Lump-Sum Damages Clauses and Settlements}

Lastly, further party involvement will be needed. One instrument that parties can already take recourse to is lump-sum damages clauses, for example, in supply contracts. According to such clauses, an undertaking that violates competition law is obliged to pay a lump-sum amount of damages to their contracting partner. ${ }^{153}$ In contrast to the above-mentioned legal presumptions of a specific amount of overcharge, lump-sum damages clauses, even included in general terms and conditions, would be agreed upon between the parties, which have a better insight into

150 See hereto also Hornkohl L.;Melzer E., Prozessualer Geheimnisschutz im Kartellschadensersatzrecht nach der 10. GWB-Novelle: Eine Novelle ohne Novellierung, NZKart, Vol. 9, No. 4, 2021, pp. 214, 219, 220.

151 Makatsch; Kacholdt, op. cit., note 41, p. 15.

152 See Lindloh K., Der Handelsrichter und sein Amt: ein Leitfaden, Gth Edition, Franz Vahlen, München, 2012.

153 See in detail Sirakova K., Pauschalierter Kartellschadensersatz in Einkaufs- und Lieferbedingungen als Alternative zur Schadensschätzung, Nomos, Baden-Baden, 2020. 
the respective market and transaction conditions and, thus, amount of possible damages. Recently, the German Federal Court of Justice has backed such an approach in Rails VI. ${ }^{154}$

Lastly, in- or out-of-court settlements between parties where precise damages calculation would not be needed should further be promoted. One possibility to promote settlements could be staggered proceedings, which are quite prominent in Dutch law ${ }^{155}$ and have been common in Germany before the Rails II case law limited the current practice ${ }^{156}$. First, courts could give interlocutory or declaratory judgments in which the courts established the liability of the defendants, now with the help of the Article 17(2)-presumption, without quantifying the exact amount of damages. ${ }^{157}$ The damages calculation is, in theory, left to a second stage. Often, the interlocutory decisions are followed by settlements. ${ }^{158}$

\section{CONCLUSION}

Quantification of harm remains a significant difficulty for parties and courts in cartel damages actions. Solutions need to balance the principle of effectiveness against other legal principles and interests. Both the presumption that cartels cause harm or a presumption concerning affected persons and products remain within the boundaries set by the Union legal framework. They incentivise and facilitate damages actions while balancing the principle of effectiveness against, particularly, the principle of non-overenforcement. Presumptions relating to the amount of harm or presumptions for other competition law infringements than cartels as defined by the Damages Directive go beyond what is necessary and would not be based on empirical findings or economic sound reasoning. The calculation of a concrete amount of damages remains subject to various different factors, which demand a case-by-case assessment. Nevertheless, damages calculation and damages actions, in general, should be further facilitated. This article proposed several strategic and legal solutions. Some of which, such as restitution or lump sum damages clauses, are already available today and satisfy claimants need for compensation, at least in part, without the need for complex, lengthy cost calculations by expensive experts. For the other proposals, such as amended calculation guidelines

\footnotetext{
154 Federal Court of Justice, 10.02.2021, KZR 63/18 - Rails VI.

155 See the proceedings in District Court of Amsterdam, 12.05.2021, C/13/639718 / HA ZA 17-1255 et al.

156 Rengier, op. cit., note 12, p. 100.

157 Rengier, op. cit., note 107, p. 75.

158 Laborde J.-F., Cartel damages actions in Europe: How courts have assessed cartel overcharges: 2018 edition, 2019, Concurrences Art. Nº 88877.
} 
or additional procedural tools, the European Commission or the Member States need to take action.

\section{REFERENCES}

\section{BOOKS AND ARTICLES}

1. Alexander C., Schadensersatz und Abschöpfung im Lauterkeits- und Kartellrecht: Privatrechtliche Sanktionsinstrumente zum Schutz individueller und überindividueller Interessen im Wettbewerb, Mohr Siebeck, Tübingen, 2010.

2. Bechtold R., Kartell ist nicht gleich Kartell: Zur Indizwirkung von Bußgeldentscheidungen für den Schaden der Marktgegenseite und zur Bindungswirkung für den Schadensrichter, in: Europäisches, deutsches und internationales Kartellrecht, Otto Schmidt, Köln, 2018.

3. Bernatt M.; Gac M., Poland, in: The EU Antitrust Damages Directive: Transposition in the Member States, Oxford University Press, Oxford, 2018.

4. Bernhard K., Making victims whole: A restitution approach to cartel damages, Concurrences Review, No. 1, Art. No. 41907, 2012.

5. Bodnár Miskolczi P., Hungary, in: Implementation of the EU Damages Directive in Central and Eastern European countries, University of Warsaw Faculty of Management Press, Warsaw, 2017.

6. Bolotova Y., Cartel overcharges: An empirical analysis, Journal of Economic Behavior \& Organization, Elsevier, Vol. 70, No. 1-2, 2009.

7. Botta M., The Principle of Passing on in EU Competition Law in the Aftermath of the Damages Directive, European Review of Private Law, Wolters Kluwer, Vol. 25, No. 5, 2017.

8. Boyer M.; Kotchoni R., How Much Do Cartel Overcharge? Review of Industrial Organization, Springer, Vol. 47, No. 2, 2015.

9. Brömmelmeyer C., Die Ermittlung des Kartellschadens nach der Richtlinie 2014/104/EU, Neue Zeitschrift für Kartellrecht, Nomos, Vol. 4, No. 1, 2016.

10. Campbell S.; Feunteun T., Designing a Balanced System: Damages, Deterrence, Leniency and Litigants' Rights - A Claimant's Perspective in: European Competition Law Annual 2011: Integrating Public and Private Enforcement, Implications for Courts and Agencies, Hart Publishing, 2014

11. Cauffman C., Belgium, in: The EU Antitrust Damages Directive: Transposition in the Member States, Journal of European Competition Law \& Practice, Oxford University Press, Vol. 9, No. 8, 2018.

12. Cohen M.; Scheffman D., The Antitrust Sentencing Guideline: Is the Punishment Worth the Costs, American Criminal Law Review, Georgetown University Law Center, Vol. 27, No. 2, 1989.

13. Connor J.; Bolotova Y., Cartel Overcharges: Survey and Meta-Analysis, International Journal of Industrial Organization, Elsevier, Vol. 24, No. 6, 2006.

14. Connor J.; Lande R., How High Do Cartels Raise Prices? Implications for Optimal Cartel Fines, Tulane Law Review, Vol. 80, 2005. 
15. Connor J.; Lande R., Cartel Overcharges and Optimal Cartel Fines, in: Issues in Competition Law and Policy, American Bar Association Section of Antitrust Law, 2008.

16. Coppik J.; Heimeshoff U., Praxis der Kartellschadensermittlung: Empirische Evidenz zur Effektivität von Kartellen, Wirtschaft und Wettbewerb, Handelsblatt Fachmedien, Vol. 70, No. 11, 2020.

17. Deselaers W., Anscheinsbeweis für das Entstehen eines Schadens bei bloßem Informationsaustausch?, in: Europäisches, deutsches und internationales Kartellrecht, Otto Schmidt, Köln, 2018.

18. Dreher M., Die Anfechtung und Abwicklung kartellbefangener Verträge nach $\$ \$ 123,812$ ff. BGB: Bereicherungsrecht als Alternative zum kartellrechtlichen Schadenersatz, in: Kartellrecht in Theorie und Praxis: Festschrift für Cornelis Canenbley zum 70. Geburtstag, C.H. Beck, München, 2012.

19. Ellger R., Kartellschaden und Verletzergewinn, in: Recht, Ordnung und Wettbewerb: Festschrift zum 70. Geburtstag von Wernhard Möschel, Nomos, Baden-Baden, 2011.

20. Filippelli M., Presumption of harm in cartel damages cases, European Competition Law Review, Sweet \& Maxwell, Vol. 41, No. 3, 2020.

21. Franck J.-U., Umbrella pricing and cartel damages under EU competition law, European Competition Journal, Routledge, Vol. 11, No. 1, 2015.

22. Fritzsche A., Die Schadensvermutung: Auslegungsfragen zum Kartellzivilrecht nach der 9. GWB-Novelle, Neue Zeitschrift für Kartellrecht, Nomos, Vol. 5, No. 11, 2017.

23. Hempel R., Privater Rechtsschutz im deutschen Kartellrecht nach der 7 GWB-Novelle, Wirtschaft und Wettbewerb, Handelsblatt Fachmedien, Vol. 54, No. 4, 2004.

24. Hess B., Europäisches Zivilprozessrecht, 2nd Edition, De Gruyter, Berlin, 2020.

25. Hornkohl L., The protection of confidential information during the disclosure of evidence according to the Damages Directive, European Competition Law Review, Sweet \& Maxwell, Vol. 41, No. 2, 2020.

26. Hornkohl L., Freie Schätzung der Kartellschadenshöhe nach S 287 ZPO: Eine Reaktion auf jüngste Entwicklungen, Neue Zeitschrift für Kartellrecht, Nomos, Vol. 8, No. 12, 2020.

27. Hornkohl L., Geschäftsgeheimnisschutz im Kartellschadensersatzrecht: Die Offenlegung von Beweismitteln und der Schutz von Geschäftsgeheimnissen im Kartellschadensersatzrecht nach Umsetzung der Kartellschadensersatzrichtlinie Mohr Siebeck, Tübingen, 2021 forthcoming.

28. Hornkohl L.; Melzer E., Prozessualer Geheimnisschutz im Kartellschadensersatzrecht nach der 10. GWB-Novelle: Eine Novelle ohne Novellierung, Neue Zeitschrift für Kartellrecht, Nomos, Vol. 9, No. 4, 2021.

29. Howard A., Too little, too late?: The European Commission's Legislative Proposals on Anti-Trust Damages Actions, Journal of European Competition Law \& Practice, Oxford Universitiy Press, Vol. 4, No. 6, 2013.

30. Hüschelrath K.; Müller K.; Veith T., Concrete Shoes for Competition: The Effect of the German Cement cartel on market price, Journal of Competition Law \& Economics, Oxford University Press, Vol. 9, No. 1, 2013. 
31. Iacovides M., The Presumption and Quantification of Harm in the Directive and the Practical Guide, in: Harmonising EU competition litigation: The new directive and beyond, Hart Publishing, 2015.

32. Idot L., The international aspects of private enforcement after the Directive 2014/104/EU: Gaps in the EU system and competition between national laws, Concurrences Review, No. 2, Art. No. 83833, 2017.

33. Inderst R.; Schwalbe U., Das kontrafaktische Szenario bei der Berechnung von Kartellschäden, Wirtschaft und Wettbewerb, Handelsblatt Fachmedien, Vol. 62, No. 2, 2012.

34. Inderst R.; Thomas S., Schadensersatz bei Kartellverstößen: Juristische und ökonomische Grundlagen und Methoden, 2nd Edition, Handelsblatt Fachmedien, 2018.

35. Isikay O., Schadensschätzung bei Kartellverstößen — was kann das Kartellrecht vom Zivilrecht lernen?: Die Analyse zweier zivilrechtlicher Schadensphänomene, Ducker \& Humblot, Berlin, 2020.

36. Kahle, Die Leistungskondiktion als Alternative zum Kartellschadensersatzanspruch: Zur Anfechtbarkeit und Rückabwicklung von Kartellfolgeverträgen, Nomos, Baden-Baden, 2013.

37. Kersting C., Kartellschadensersatzrecht nach der 9. GWB-Novelle, Zeitschrift Versicherungsrecht, Verlag Versicherungswirtschaft, Vol. 68, No. 10, 2017.

38. Kersting C., 15 \% Preisaufschlag: Freie Schätzung des Kartellschadens beim Schienenkartell, Wirtschaft und Wettbewerb, Handelsblatt Fachmedien, Vol. 70, No. 11, 2020.

39. Kersting C.; Preuß N., Umsetzung der Kartellschadensersatzrichtlinie (2014/104/EU): Ein Gesetzgebungsvorschlag aus der Wissenschaft, Nomos, Baden-Baden, 2015.

40. Klumpe G.; Thiede T., Regierungsentwurf zur 9. GWB-Novelle: Änderungsbedarf aus Sicht der Praxis, Betriebs Berater, dfv Mediengruppe, No. 50, 2016.

41. Laborde J.-F., Cartel damages actions in Europe: How courts have assessed cartel overcharges: 2018 edition, Concurrences Review, No. 4, Art. No. 88877, 2019.

42. Laborde J.-F., Cartel damages actions in Europe: How courts have assessed cartel overcharges: 2019 edition, Concurrences Review, No. 4, Art. No. 92227, 2019.

43. Lindloh K., Der Handelsrichter und sein Amt: ein Leiffaden, 6th Edition, Franz Vahlen, München, 2012.

44. Makatsch T.; Kacholdt B., Estimation of cartel damages in competition litigation in Germany: 15 per cent as the new standard?, Global Competition Litigation Review, Sweet \& Maxwell, Vol. 14, No. 1, 2021.

45. Malinauskaite J.; Cauffman C., The Transposition of the Antitrust Damages Directive in the Small Member States of the EU: A Comparative Perspective, Journal of European Competition Law \& Practice, Oxford University Press, Vol. 9, No. 8, 2018.

46. Mankowski P.; Schreier M., Zum Begriff des Wertes und des üblichen Preises, insbesondere in $\mathbb{S}$ 818 Abs 2 BGB: Zugleich zur Verzahnung von Zivil- und Kartellrecht, Archiv für die civilistische Praxis, Mohr Siebeck, Vol. 208, No. 6, 2008.

47. Maslow C., Der Schutz des immateriellen Erfüllungsinteresses bei Vertragsverletzung durch Schadensersatz: Eine rechtsvergleichende Untersuchung auf der Grundlage des deutschen und englischen Rechts, Mohr Siebeck, Tübingen, 2015. 
48. Meeßen G., Der Anspruch auf Schadensersatz bei Verstößen gegen EU-Kartellrecht: Konturen eines Europäischen Kartelldeliktsrechts?, Mohr Siebeck, Tübingen, 2011.

49. Mikelenas V.; Zaščiurinskaite R., Quantification of Harm and the Damages Directive: Implementation in CEE Countries, Yearbook of Antitrust and Regulatory Studes, Vol. 10, No. 15, 2017.

50. Möllers T.; Heinemann A., The enforcement of competition law in Europe, Cambridge University Press, 2007.

51. Nagy C., Schadensersatzklagen im Falle kartellrechtlicher Rechtsverletzungen in Ungarn, Wettbewerb und Wirtschaft, Handelsblatt Fachmedien, Vol. 60, No. 9, 2010

52. Noble R.: Pilsbury S., Is 10 per cent the answer? The role of legal presumptions in private competition litigation, Global Competition Litigation Review, Sweet \& Maxwell, Vol. 1, No. 3, 2008.

53. Otto J., (Kartell-)Betroffenheit und Schadensallokation nach der 9. GWB-Novelle, Zeitschrift für Wettbewerbsrecht, Handelsblatt Fachmedien, Vol. 17, No. 4, 2019.

54. Piszcz A.; Wolski D., Poland, in: Implementation of the EU Damages Directive in Central and Eastern European countries, University of Warsaw, Faculty of Management Press, 2017.

55. Posner R., The Social Costs of Monopoly and Regulation, Journal of Political Economy, University of Chicago Press, Vol. 83, No. 4, 1975.

56. Rauh J., Vom Kartellantengewinn zum ersatzfähigen Schaden: Neue Lösungsansätze für die private Rechtsdurchsetzung, Neue Zeitschrift für Kartellrecht, Nomos, Vol. 1, No. 6, 2013.

57. Rauh J., Zuchandke A.; Reddemann S., Die Ermittlung der Schadenshöhe im Kartelldeliktsrecht, Wettbewerb in Recht und Praxis, dfv Mediengruppe, Vol. 58, 2012.

58. Rengier L., Cartel Damages Actions in German Courts: What the Statistics Tell Us, Journal of European Competition Law \& Practice, Oxford University Press, Vol. 11, No. 1-2, 2020.

59. Rengier L., The German Federal Court of Justice's judgment in Rails II: Shifting the focus from liability to quantum in cartel damages?, Global Competition Litigation Review, Sweet \& Maxwell, Vol. 13, No. 3, 2020.

60. Rinnen F.; Wandschneider F., Ökonomische Überlegungen zur freien Schätzung des Kartellschadens durch das LG Dortmund, Neue Zeitschrift für Kartellrecht, Nomos, Vol. 9, No. 1, 2021.

61. Şahin E., Collective Redress and EU Competition Law, Routledge, 2018.

62. Sirakova K., Pauschalierter Kartellschadensersatz in Einkaufs- und Lieferbedingungen als Alternative zur Schadensschätzung, Nomos, Baden-Baden, 2020.

63. Smuda F., Cartel Overcharges and the Deterrent Effect of EU Competition Law, Journal of Competition Law \& Economics, Vol. 10, No. 1, 2014.

64. Soyez V., Germany "Rail Cartel II": German Federal Supreme Court further strengthens private enforcement in Germany, Global Competition Litigation Review, Sweet \& Maxwell, Vol. 13, No. 4, 2020.

65. Strand M., Labours of harmony: Unresolved issues in competition damages, European Competition Law Review, Sweet \& Maxwell, Vol. 38, No. 5, 2017.

66. Thiede T., Zur Schätzung des Kartellschadens, Neue Zeitschrift für Kartellrecht, Nomos, Vol. 8, No. 12, 2020. 
67. Thole C., Freie Mindestschadensschätzung nach $\$ 287$ ZPO durch das Gericht?: Das Urteil des LG Dortmund vom 30.9.2020 auf dem Prüfstand des Prozessrechts, Neue Zeitschrift für Kartellrecht, Nomos, Vol. 9, No. 1, 2021.

68. Weidt C., The Directive on actions for antitrust damages after passing the European Parliament, European Competition Law Review, Sweet \& Maxwell, Vol. 35, No. 9, 2014.

69. Westermann K., $\$ 11$ Zivilrechtliche Nichtigkeit kartellrechtswidriger Verträge und einseitiger Rechtsgeschäfte, bereicherungsrechtliche Rückabwicklung kartellrechtswidriger Verträge, in: Handbuch Private Kartellrechtsdurchsetzung, C.H. Beck, München, 2019.

70. Woeste K., Bereicherungsrecht als Alternative zum Kartellschadensersatz: Passing-on defense im Bereicherungsausgleich?, Zeitschrift für Wettbewerbsrecht, Handelsblatt Fachmedien, Vol. 16, No. 4, 2018.

71. Wurmnest W., Forum Shopping bei Kartellschadensersatzklagen und die Kartellschadensersatzrichtlinie, Neue Zeitschrift für Kartellrecht, Nomos, Vol. 5, No. 1, 2017.

72. Ysewyn J.; Kahmann S., The decline and fall of the leniency programme in Europe, Concurrences Review, No. 1, Art. No. 86060, 2018.

\section{COURT OF JUSTICE OF THE EUROPEAN UNION}

1. Case C-298/04 Manfredi [2004] ECLI:EU:C:2006:461.

2. Case C-557/12 Kone [2014] ECLI:EU:C:2014:1317.

3. Case C-435/18 Otis [2019] ECLI:EU:C:2019:1069.

\section{EU LAW}

1. Treaty of Lisbon amending the Treaty on European Union and the Treaty establishing the European Community [2007] OJ C306/01.

2. Directive 2014/104/EU of the European Parliament and of the Council of 26 November 2014 on certain rules governing actions for damages under national law for infringements of the competition law provisions of the Member States and of the European Union [2014] OJ L 349/1.

3. Directive (EU) 2020/1828 of the European Parliament and of the Council of 25 November 2020 on representative actions for the protection of the collective interests of consumers and repealing Directive 2009/22/EC [2020] OJ L 409/1.

4. European Commission, Commission Staff Working Paper accompanying the White Paper on Damages Actions for breach of EC antitrust rules, (SEC (2008) 404), [https://eur-lex.europa. eu/legal-content/EN/TXT/PDF/?uri=CELEX:52008SC0404\&from=EN], Accessed 20 April 2021.

5. European Commission, Explanatory Memorandum: Proposal for a Directive of the European Parliament and the Council on certain rules governing actions for damages under national law for infringements of the competition law provisions of the Member States and of the European Union, (COM (2013) 404 final) [https://eur-lex.europa.eu/legal-content/EN/TXT/PDF/? uri=CELEX:52013PC0404\&from=EN], Accessed 20 April 2021. 


\section{LIST OF NATIONAL REGULATIONS, ACTS AND COURT DECISIONS}

1. Burgerlijk Wetboek Nederland.

2. Code de droit économique, Moniteur belge du 29.03.2013, 19975.

3. Decreto Legislativo 19 gennaio 2017, n. 3, GU Serie Generale n.15 del 19-01-2017.

4. District Court of Amsterdam, 12.05.2021, C/13/639718 / HA ZA 17-1255 et al.

5. European Union (Actions for Damages for Infringements of Competition Law) Regulations 2017, S.I. No. 43/2017.

6. Federal Court of Justice, 11.12.2018, KZR 26/17 - Rails I.

7. Federal Court of Justice, 28.01.2020, KZR 24/17 - Rails II.

8. Federal Court of Justice, 10.02.2021, KZR 63/18 - Rails VI.

9. Gesetz gegen Wettbewerbsbeschränkungen in der Fassung der Bekanntmachung vom 26. Juni 2013 (BGBl. I S. 1750, 3245), das zuletzt durch Artikel 30 des Gesetzes vom 23. Juni 2021 (BGBl. I S. 1858) geändert worden ist.

10. Higher Regional Court Düsseldorf, 23.01.2019, U (Kart) 17/17.

11. Konkurences likums, Latvijas Vēstnesis, 151, 23.10.2001.

12. Lei 23/2018, de 5 de junho - direito a indemnização por infração ao direito da concorrência, Diário da República, 1. ${ }^{a}$ série - N.o 107.

13. Ley $15 / 2007$, de 3 de julio, de Defensa de la Competencia, Boletín Oficial del Estado, Núm. 159, de 4 de julio de 2007, Sec. I. Pág. 28848.

14. Loi du 5 décembre 2016 relative à certaines règles régissant les actions en dommages et intérêts pour les violations du droit de la concurrence, A245.

15. ORDONANȚĂ DE URGENȚĂ nr. 170 din 14 octombrie 2020, privind acțiunile în despăgubire în cazurile de încălcare a dispozițiilor legislației în materie de concurență, precum și pentru modificarea și completarea Legii concurenței nr. 21/1996, MONITORUL OFICIAL nr. 952 din 16 octombrie 2020.

16. Real Decreto-ley $9 / 2017$, de 26 de mayo, por el que se transponen directivas de la Unión Europea en los ámbitos financiero, mercantil y sanitario, y sobre el desplazamiento de trabajadores, Boletín Oficial del Estado, Núm. 126, de 27 de mayo de 2017, Sec. I. Pág. 42820.

17. Regional Court Dortmund, 30.09.2020, 8 O 115/14 (Kart).

18. Ustawa z dnia 21 kwietnia 2017 r. o roszczeniach o naprawienie szkody wyrządzonej przez naruszenie prawa konkurencji.

19. 1996. évi LVII. törvény a tisztességtelen piaci magatartás és a versenykorlátozás tilalmáról, Magyar Közlöny 1996/56, 03498.

20. 2018 United States Sentencing Commission Guidelines Manual.

21. European Commission, Impact Assessment Report Damages actions for the breach of the EU antitrust rules, (SWD (2013) 203 final) [https://ec.europa.eu/competition/antitrust/actionsdamages/impact_assessment_en.pdf], Accessed 20 April 2021.

22. European Commission, Practical Guide Quantifying Harm in Actions for Damages Based on Breaches of Article 101 or 102 of the TFEU, (SWD (2013) 205) [https://ec.europa.eu/competition/antitrust/actionsdamages/quantification_guide_en.pdf], Accessed 20 April 2021. 


\section{WEBSITE REFERENCES}

1. Connor JM., Price-Fixing Overcharges: Legal and Economic Evidence (2005) [https://ssrn. com/abstract=787924], Accessed 20 April 2021.

2. Connor JM., Price Fixing Overcharges: Revised $2^{\text {nd }}$ Edition (2008) [https://ssrn.com/abstract=1610262], Accessed 20 April 2021.

3. Connor JM., Price-Fixing Overcharges: Revised 3 $3^{\text {rd }}$ Edition (2014) [https://ssrn.com/abstract=2400780], Accessed 20 April 2021.

4. Maier-Rigaud F; Milde C.; Helm M., Textbook Cartels versus the Real Deal: Should We Be Surprised if Some Cartels Do Not Lead to Damage?, (2015) [https://ssrn.com/abstract=2578317], Accessed 20 April 2021.

5. Organisation for Economic Co-operation and Development (OECD), 'Report on the Nature and Impact of Hard Core Cartels and Sanctions Against Cartels Under National Competition Laws' (2002), [https://www.oecd.org/daf/competition/cartels/2081831.pdf], Accessed 20 April 2021.

6. Oxera, Quantifying antitrust damages: Towards non-binding guidance for courts, (2009) [https://ec.europa.eu/competition/antitrust/actionsdamages/quantification_study.pdf], Accessed 20 April 2021. 